IZA DP No. 6565

Endogenous Exit Bias in Training Programs for Unemployed Workers

Jochen Kluve

Ulf Rinne

Arne Uhlendorff

Zhong Zhao

May 2012 


\title{
Endogenous Exit Bias in Training Programs for Unemployed Workers
}

\author{
Jochen Kluve \\ Humboldt University Berlin, \\ $R W I$ and IZA \\ Ulf Rinne \\ IZA
}

Arne Uhlendorff University of Mannheim,

DIW Berlin, IAB and IZA

\author{
Zhong Zhao \\ Renmin University of China \\ and IZA
}
Discussion Paper No. 6565
May 2012

IZA

P.O. Box 7240

53072 Bonn

Germany

Phone: +49-228-3894-0
Fax: +49-228-3894-180
E-mail: iza@iza.org

Any opinions expressed here are those of the author(s) and not those of IZA. Research published in this series may include views on policy, but the institute itself takes no institutional policy positions.

The Institute for the Study of Labor (IZA) in Bonn is a local and virtual international research center and a place of communication between science, politics and business. IZA is an independent nonprofit organization supported by Deutsche Post Foundation. The center is associated with the University of Bonn and offers a stimulating research environment through its international network, workshops and conferences, data service, project support, research visits and doctoral program. IZA engages in (i) original and internationally competitive research in all fields of labor economics, (ii) development of policy concepts, and (iii) dissemination of research results and concepts to the interested public.

IZA Discussion Papers often represent preliminary work and are circulated to encourage discussion. Citation of such a paper should account for its provisional character. A revised version may be available directly from the author. 
IZA Discussion Paper No. 6565

May 2012

\section{ABSTRACT \\ Endogenous Exit Bias in Training Programs for Unemployed Workers}

This paper assesses the importance of reverse causality when evaluating the impact of training duration for unemployed workers. We use planned duration as an instrumental variable for actual duration. Our results suggest that the potential endogeneity of exits seems to be only relevant in the lower and upper part of the treatment duration distribution.

JEL Classification: $\quad \mathrm{C} 21, \mathrm{C} 26, \mathrm{~J} 67$

Keywords: treatment duration, local average treatment effect, dropouts

Corresponding author:

Zhong Zhao

School of Labor and Human Resources

Renmin University of China

59 Zhongguancun Ave

Beijing 100872

China

E-mail: mr.zhong.zhao@gmail.com 


\section{Introduction}

Sample selection bias is the central issue in the treatment effect literature. It arises because treatment and control groups are usually formed through selfselection instead of randomization (see, e.g., Heckman et al., 1999). Another potentially important form occurs if treated observations leave the program before receiving full treatment. Since dropouts might be endogenously determined, a bias could result. Heckman et al. (1998) and Heckman et al. (2000) find that this dropout bias is indeed significant. They analyze this issue in a binary setting, but in reality treatment usually lasts for a certain period of time. As treatment effects can be heterogeneous in treatment duration, it is important to know whether (and how) effects vary. Recent contributions analyzing the impact of continuous training durations include Flores et al. (2012) and Kluve et al. (2012). Both studies apply generalized propensity score methods and find a slightly positive impact of increasing training durations on employment outcomes, especially for shorter durations.

In the framework with continuous training durations, participants may leave the program early because they find employment or expect no further benefits. Participants could also stay longer than planned, e.g., to prolong benefit entitlement. These examples imply that treatment effect estimates based on actual training durations might be biased in either direction. We analyze this issue with data containing both actual and planned training durations. This allows us to use the planned duration as an instrumental variable for the actual duration and, hence, to directly quantify the importance of endogenous exits. ${ }^{1}$

\section{Institutional Background and Data}

Access to training programs in Germany is based on the decision of the caseworker. In our data period (2000-2002) the caseworker specifies the type, the content and the duration of the training. The caseworker takes various factors into consideration including the aptitude of her client for a certain job, the likelihood to succeed in the training program, the local labor market conditions and training costs. It is thus reasonable to assume that once we condition on the large set of observed characteristics that are available to us, importantly including previous labor market outcomes, the decision about the planned pro-

\footnotetext{
${ }^{1}$ Fitzenberger et al. (2010) analyze the impact of training duration measured by yearly quarters. They model endogenous exits based on time-invariant unobserved characteristics and find a positive impact of training participation on employment outcomes, but they do not explicitly estimate the bias caused by endogenous exits.
} 
gram duration can be regarded as independent of the participants' future labor market outcomes.

We consider classroom oriented training and more practically oriented programs with only a few theoretical parts. Participants in these programs either learn specific skills required for a certain vocation or receive qualifications of general vocational use (see Kluve et al., 2012, who use the same data).

We use a sample of a rich administrative data set, the Integrated Employment Biographies (IEB). The data contain daily information on employment subject to social security contributions, receipt of transfer payments during periods of unemployment, participation in different ALMP measures, and covariates like age, education, disability, nationality and regional characteristics. We know both the initial length of the treatment participants were assigned to and the actual program duration.

Most participants in our sample stay in the program exactly as long as planned (72.1\%). Early exits are more than twice as common as late exits (19.5\% and $8.4 \%$, respectively). The covariate distributions are rather similar across all subgroups, see Table 1 . However, if we estimate a multinomial probit model for leaving the program before, exactly at, or after the planned exit, observed factors appear important for the selection into early exits. Early dropouts are negatively correlated with age, vocational attainment, previous unemployment duration and local unemployment rates. For late exits we observe that male participants are more likely to stay in the program longer than planned.

$$
\text { Table } 1 \text { about here }
$$

Our outcome variable is the employment probability two years after program entry. About $35 \%$ of the participants are employed at this stage and early exits, planned exits and late exits exhibit almost the same employment probabilities, see Figure 1.

\section{Figure 1 about here}

However, employment probabilities are quite different initially. For planned exits and late exits, after a period of about 180 days in which participants appear "locked-in" (van Ours, 2004), employment probabilities increase relatively steeply. In contrast, the employment probability of early exits sharply increases immediately after program entry. Early exits thus seem to "benefit" from their dropout, which could indicate that some individuals leave the program early because they find employment. 


\section{Estimation approach and results}

We discretize the actual program duration using five different cutoff points (at the $15 \%, 30 \%, 50 \%, 70 \%$ and $85 \%$ percentiles, i.e., at $89,145,182,249$ and 306 days) to define groups with shorter vs. longer treatment duration. The indicator " 1 " means that the participants have a longer duration than a given cutoff point. Then we run five standard probit models with this dummy variable as our main independent variable (along with other observed characteristics $X$ ). The coefficient of the dummy variable is the treatment effect from the program duration. In case of endogenous exits, the actual program duration is endogenous, and so is the constructed dummy variable. Hence, estimated coefficients could be biased.

To assess the importance of this potential bias, we use the planned duration as an instrumental variable (IV) for the actual duration. More specifically, we also discretize the planned duration accordingly, and we use the dummy variable created from the planned duration as an instrument for the dummy variable created from the actual duration. This gives us an estimate of the local average treatment effect (LATE) as developed in Imbens and Angrist (1994). The difference between the standard probit estimates and the IV estimates then reflects the dropout bias since the latter approach controls for endogenous exits. We apply generalized Hausman tests to formally assess the statistical significance of any differences.

This approach assumes that the planned treatment duration is exogenous. ${ }^{2}$ There are mainly two arguments supporting this assumption. First, the planned duration is determined prior to the program, which is arguably exogenous. Second, our data include very rich information-importantly including the previous labor market history. Although this does not help to control for potential selection into planned program duration based on unobserved variables, it seems plausible that the planned duration is exogenous once we control for the detailed observed characteristics.

Table 2 displays the results from the IV approach in comparison to standard probit estimates. Next to the models with continuous durations, we present results for the different models $1-5$ which correspond to the different cutoff points and therefore estimate different LATE.

Table 2 about here

The majority of our estimates are insignificant when the outcome variable is the employment status two years after program entry. There are only two

${ }^{2}$ Planned and actual treatment durations are significantly positively correlated. 
exceptions to this general statement. First, we find in some models significantly positive estimates for lower cutoff points. This indicates that an increase of the training duration has a positive impact on employment outcomes in the lower part of the duration distribution. This is in line with the results of Kluve et al. (2012). Second, we find in some models significantly negative estimates for higher cutoff points. This indicates that longer durations impact employment outcomes negatively in the upper part of the duration distribution.

The generalized Hausman tests do not reject the Null hypothesis of no systematic differences between the coefficient estimates for the vast majority of estimates. Reverse causality thus seems in general not very important. However, some evidence suggests that the positive impacts of longer treatment durations at lower cutoff points are underestimated in the standard approach. In contrast, the negative impacts at higher cutoff points appear slightly more negative when taking into account endogenous exits. Therefore, and in line with descriptive evidence, early dropouts in the lower part of the treatment duration distribution may actually leave earlier than planned to take up employment, whereas early dropouts with longer planned treatment durations seem to increasingly leave because of frustration.

Since Figure 1 suggests that the employment probability of early exits is different from the other subgroups, we carry out the same analysis of endogenous exits for the sample including only planned exits and early exits. The corresponding results in the right part of Table 2 are similar to the full sample results. $^{3}$

\section{Conclusions}

Endogenous exits from training programs lead to a bias in treatment effect estimates if based on actual training durations. This bias results from reverse causality. However, our results suggest that reverse causality is in general not very important. It seems to be only relevant in the lower and upper part of the treatment duration distribution.

\footnotetext{
${ }^{3}$ We find significantly negative impacts of longer treatment durations on employment outcomes if we consider the employment status 18 months after program entry as outcome variable. However, the results on the endogenous exit bias are similar to the results presented here.
} 


\section{References}

Fitzenberger, B., Osikominu, A., Paul, M., 2010. The Heterogeneous Effects of Training Incidence and Duration on Labor Market Transitions. IZA Discussion Paper 5269, Institute for the Study of Labor (IZA).

Flores, C., Flores-Lagunes, A., Gonzalez, A., Neuman, T., 2012. Estimating the Effects of Length of Exposure to Instruction in a Training Program: The Case of Job Corps. Review of Economics and Statistics 94 (1), 153-171.

Heckman, J. J., Hohmann, N., Smith, J. A., Khoo, M., 2000. Substitution and Dropout Bias in Social Experiments: A Study of an Influential Social Experiment. Quarterly Journal of Economics 115 (2), 651-694.

Heckman, J. J., LaLonde, R. J., Smith, J. A., 1999. The Economics and Econometrics of Active Labor Market Programs. In: Ashenfelter, O., Card, D. (Eds.), Handbook of Labor Economics. Vol. 3. Elsevier, Amsterdam, Ch. 31, pp. 1865-2097.

Heckman, J. J., Smith, J. A., Taber, C., 1998. Accounting for Dropouts in Evaluations of Social Programs. Review of Economics and Statistics 80 (1), 1-14.

Imbens, G., Angrist, J., 1994. Identification and Estimation of Local Average Treatment Effects. Econometrica $62(2), 467-475$.

Kluve, J., Schneider, H., Uhlendorff, A., Zhao, Z., 2012. Evaluating continuous training programs by using the generalized propensity score. Journal of the Royal Statistical Society, Series A (Statistics in Society) 175 (2), 587-617.

van Ours, J. C., 2004. The Locking-in Effect of Subsidized Jobs. Journal of Comparative Economics $32(1), 37-55$. 
Figure 1: Unadjusted employment probabilities after program entry.

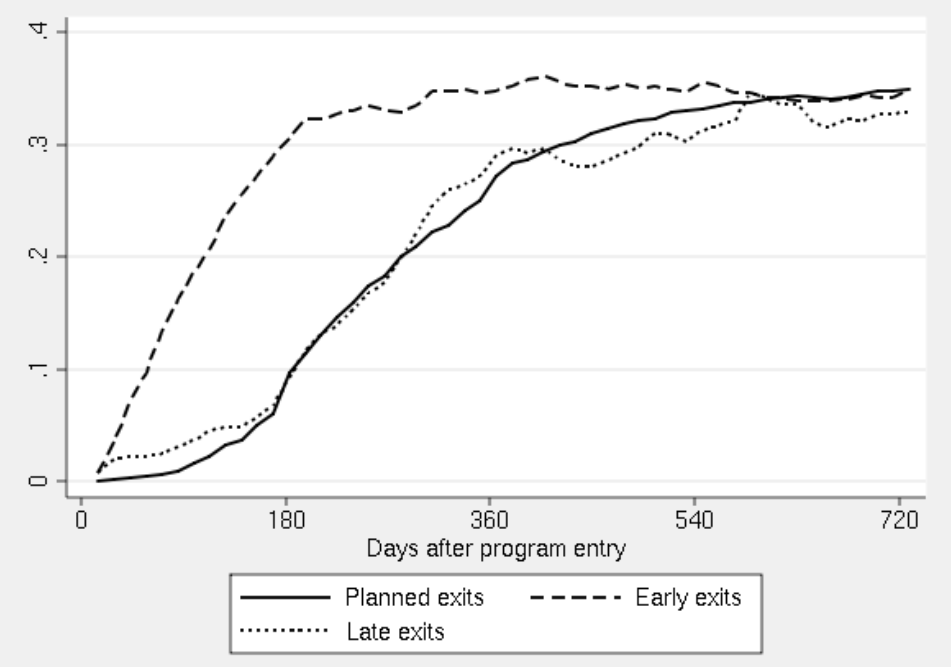


Table 1: Summary statistics.

\begin{tabular}{|c|c|c|c|c|}
\hline & $\begin{array}{c}\text { Full } \\
\text { Sample }\end{array}$ & $\begin{array}{l}\text { Early } \\
\text { Exits }\end{array}$ & $\begin{array}{l}\text { Late } \\
\text { Exits }\end{array}$ & $\begin{array}{l}\text { Planned } \\
\text { Exits }\end{array}$ \\
\hline Male & 0.51 & 0.58 & 0.54 & 0.48 \\
\hline Age & 37.49 & 36.14 & 37.88 & 37.81 \\
\hline $\begin{array}{l}\text { Disability } \\
\text { Low degree } \\
\text { Medium degree } \\
\text { High degree }\end{array}$ & $\begin{array}{l}0.06 \\
0.00 \\
0.00\end{array}$ & $\begin{array}{l}0.08 \\
0.00 \\
0.00\end{array}$ & $\begin{array}{l}0.03 \\
0.00 \\
0.00\end{array}$ & $\begin{array}{l}0.06 \\
0.00 \\
0.01\end{array}$ \\
\hline $\begin{array}{l}\text { Citizenship } \\
\text { Foreigner EU } \\
\text { Foreigner Non-EU }\end{array}$ & $\begin{array}{l}0.02 \\
0.08\end{array}$ & $\begin{array}{l}0.02 \\
0.09\end{array}$ & $\begin{array}{l}0.01 \\
0.11\end{array}$ & $\begin{array}{l}0.01 \\
0.08\end{array}$ \\
\hline $\begin{array}{l}\text { Educational attainment } \\
\text { No graduation } \\
\text { First stage of secondary level } \\
\text { Second stage of secondary level } \\
\text { Advanced tech. college entrance qualification } \\
\text { General qualification for university entrance }\end{array}$ & $\begin{array}{l}0.09 \\
0.44 \\
0.33 \\
0.04 \\
0.09\end{array}$ & $\begin{array}{l}0.13 \\
0.50 \\
0.29 \\
0.03 \\
0.06\end{array}$ & $\begin{array}{l}0.07 \\
0.44 \\
0.34 \\
0.05 \\
0.10\end{array}$ & $\begin{array}{l}0.09 \\
0.43 \\
0.34 \\
0.04 \\
0.10\end{array}$ \\
\hline $\begin{array}{l}\text { Vocational attainment } \\
\text { No vocational degree } \\
\text { In-plant training } \\
\text { Off-the-job training, voc. school, tech. school } \\
\text { University, advanced technical college }\end{array}$ & $\begin{array}{l}0.31 \\
0.56 \\
0.07 \\
0.06\end{array}$ & $\begin{array}{l}0.41 \\
0.50 \\
0.06 \\
0.03\end{array}$ & $\begin{array}{l}0.28 \\
0.58 \\
0.07 \\
0.07\end{array}$ & $\begin{array}{l}0.29 \\
0.57 \\
0.07 \\
0.07\end{array}$ \\
\hline $\begin{array}{l}\text { Employment history } \\
\text { Previous unemployment duration in months } \\
\text { Duration of last employment in months } \\
\text { Log(wage) last employment } \\
\text { No last employment observed }\end{array}$ & $\begin{array}{r}9.43 \\
20.76 \\
3.38 \\
0.11\end{array}$ & $\begin{array}{r}9.05 \\
16.95 \\
3.35 \\
0.10\end{array}$ & $\begin{array}{r}9.08 \\
23.26 \\
3.39 \\
0.12\end{array}$ & $\begin{array}{r}9.58 \\
21.50 \\
3.39 \\
0.11\end{array}$ \\
\hline $\begin{array}{l}\text { Share of days in employment before progra } \\
\text { 1st year } \\
\text { 2nd year } \\
\text { 3rd year } \\
\text { 4th year }\end{array}$ & $\begin{array}{l}0.18 \\
0.36 \\
0.39 \\
0.41\end{array}$ & $\begin{array}{l}0.18 \\
0.36 \\
0.39 \\
0.39\end{array}$ & $\begin{array}{l}0.19 \\
0.38 \\
0.39 \\
0.41\end{array}$ & $\begin{array}{l}0.18 \\
0.36 \\
0.39 \\
0.41\end{array}$ \\
\hline $\begin{array}{l}\text { Share of days in unemployment before prog } \\
\text { 1st year } \\
\text { 2nd year } \\
\text { 3rd year } \\
\text { 4th year }\end{array}$ & $\begin{array}{l}0.66 \\
0.37 \\
0.31 \\
0.27\end{array}$ & $\begin{array}{l}0.66 \\
0.39 \\
0.33 \\
0.29\end{array}$ & $\begin{array}{l}0.64 \\
0.34 \\
0.31 \\
0.27\end{array}$ & $\begin{array}{l}0.66 \\
0.36 \\
0.30 \\
0.26\end{array}$ \\
\hline $\begin{array}{l}\text { Regional characteristics } \\
\text { Local unemployment rate }\end{array}$ & 0.11 & 0.10 & 0.12 & 0.11 \\
\hline Number of observations & 5,825 & 1,138 & 489 & 4,198 \\
\hline
\end{tabular}


Table 2: Standard vs. IV estimates of treatment effects.

\begin{tabular}{|c|c|c|c|c|c|c|}
\hline & \multicolumn{3}{|c|}{ Full sample } & \multicolumn{3}{|c|}{ Planned and early exits } \\
\hline & $\begin{array}{c}\text { Probit } \\
\text { LATE (SE) }\end{array}$ & $\begin{array}{l}\text { IV Probit } \\
\text { LATE (SE) }\end{array}$ & $\begin{array}{c}G H T \\
\text { p-value }\end{array}$ & $\begin{array}{c}\text { Probit } \\
\text { LATE (SE) }\end{array}$ & $\begin{array}{l}\text { IV Probit } \\
\text { LATE (SE) }\end{array}$ & $\begin{array}{c}G H T \\
\text { p-value }\end{array}$ \\
\hline \multicolumn{7}{|c|}{ Panel A: All participants (full sample: $N=5825$; planned and early exits: $N=5336$ ) } \\
\hline Continuous & $-0.001(0.002)$ & $-0.001(0.003)$ & 0.744 & $-0.001(0.002)$ & $-0.001(0.003)$ & 0.763 \\
\hline Model 1 & $0.078(0.050)$ & $0.152(0.086)$ & 0.291 & $0.087(0.053)$ & $0.174(0.087)$ & 0.212 \\
\hline Model 2 & $0.045(0.040)$ & $0.071(0.059)$ & 0.557 & $0.044(0.042)$ & $0.064(0.060)$ & 0.642 \\
\hline Model 3 & $-0.032(0.038)$ & $0.001(0.050)$ & & $-0.016(0.040)$ & $-0.008(0.050)$ & \\
\hline Model 4 & $-0.050(0.043)$ & $-0.023(0.051)$ & 0.333 & $-0.023(0.045)$ & $-0.029(0.052)$ & 0.840 \\
\hline Model 5 & $-0.083(0.054)$ & $-0.124(0.063)$ & 0.194 & $-0.085(0.057)$ & $-0.146(0.065)$ & 0.042 \\
\hline \multicolumn{7}{|c|}{ Panel B: Male participants (full sample: $N=2951$; planned and early exits: $N=2687$ ) } \\
\hline Continuous & $0.003(0.003)$ & $0.004(0.004)$ & 0.653 & $0.003(0.003)$ & $0.002(0.004)$ & 0.845 \\
\hline Model 1 & $0.206(0.074)$ & $0.472(0.137)$ & 0.027 & $0.192(0.077)$ & $0.406(0.1403)$ & 0.078 \\
\hline Model 2 & $0.098(0.058)$ & $0.084(0.091)$ & 0.835 & $0.115(0.060)$ & $0.081(0.0895)$ & 0.615 \\
\hline Model 3 & $0.013(0.054)$ & $0.052(0.075)$ & 0.439 & $0.031(0.057)$ & $0.036(0.0735)$ & 0.911 \\
\hline Model 4 & $-0.020(0.061)$ & $0.006(0.076)$ & 0.564 & $-0.029(0.064)$ & $-0.027(0.0773)$ & 0.953 \\
\hline Model 5 & $0.022(0.077)$ & $0.001(0.095)$ & 0.699 & $0.003(0.082)$ & $-0.052(0.0983)$ & 0.297 \\
\hline \multicolumn{7}{|c|}{ Panel C: Female participants (full sample: $N=2874$; planned and early exits: $N=2642$ ) } \\
\hline Continuous & $-0.005(0.003)$ & $-0.004(0.004)$ & 0.675 & $-0.004(0.003)$ & $-0.004(0.004)$ & 0.971 \\
\hline Model 1 & $-0.037(0.072)$ & $0.133(0.115)$ & 0.066 & $0.002(0.075)$ & $0.124(0.113)$ & 0.157 \\
\hline Model 2 & $0.004(0.058)$ & $0.065(0.078)$ & 0.258 & $0.022(0.060)$ & $0.081(0.078)$ & 0.241 \\
\hline Model 3 & $-0.061(0.056)$ & $-0.079(0.068)$ & 0.643 & $-0.022(0.058)$ & $-0.020(0.069)$ & 0.972 \\
\hline Model 4 & $-0.099(0.061)$ & $-0.045(0.070)$ & 0.119 & $-0.083(0.065)$ & $-0.078(0.072)$ & 0.894 \\
\hline Model 5 & $-0.152(0.078)$ & $-0.181(0.088)$ & 0.452 & $-0.150(0.082)$ & $-0.207(0.091)$ & 0.131 \\
\hline
\end{tabular}

Notes: SE: standard error. GHT: generalized Hausman test. Dependent variable: employed 24 months after program entry. Additional control variables: see Table 1. Bold numbers indicate significance at the $5 \%$ level. Models 1-5 correspond to 5 different cutoff points, see text. Continuous training duration measured in days/10. 